\title{
Techno Legal Problems of Ensuring International and National Security
}

\author{
${ }^{1}$ Natalya A. Zhukova, ${ }^{2}$ Ol'ga N. Kichalyuk, ${ }^{3}$ Gennadij Yu. Lesnikov, ${ }^{4}$ Vladimir V. Tabolin, \\ ${ }^{5}$ Husen A. Thabisimov \\ ${ }^{1}$ Belgorod State University, 85 Pobedy St., Belgorod, 308015, Russia \\ ${ }^{2}$ The Institute of Service Sector and Entrepreneurship (Branch) of DSTU in Shakhty, 147, Shevchenko St., Shakhty, \\ Rostov Oblast, 346500, Russia \\ ${ }^{3}$ Federal State Institution Research Institute of the Federal Penitentiary Service, 14, Zhitnyaya St., Moscow, GSP-1, \\ 119991, Russia \\ ${ }^{4}$ State University of Management, 99, Ryazansky Prospect, Moscow, 109542, Russia \\ ${ }^{5}$ Pyatigorsk State University, 9, Kalinin Ave, Stavropol Region, Pyatigorsk, 357532, Russia \\ Email: zhukova_n@bsu.edu.ru
}

Received: $16^{\text {th }}$ May 2018, Accepted: 04 ${ }^{\text {th }}$ June 2018, Published: $30^{\text {th }}$ June $_{2018}$

\begin{abstract}
This paper deals with the problem of socio-economic security of the state. The paper examines possible ways of ensuring the social security of society by training personnel in public services and social workers having modern competencies that can ensure social security and create conditions for social stability and consistently solve the tasks of social and economic development in the interests of a wide range of people.
\end{abstract}

Keywords: Social Security, Economic Security, Personnel Potential

\section{Introduction}

The problems of ensuring social security have existed and solved, with a greater or lesser success in different periods of statehood, in different countries. These problems existed and were represented differently in the Russian Empire, in the Soviet Union, in the Russian Federation, but they differed much from the current agenda.

In the second decade of the twenty-first century, Russia, like a number of other modern states, faced new challenges that threatened its stable social and economic development. Searching for and finding of appropriate solutions and the related problems at different levels such as state, methodological, sociotechnological, is an extremely urgent task. By solving the problems of ensuring its national security, the Russian Federation simultaneously helps other countries and their people facing similar challenges to solve address them. To the extent that we, in general, will cope with these tasks, largely depends on the entire socio-economic situation and the living conditions of the population of our countries in the near future.

\section{Methodology}

In our study we used general scientific methods and techniques of logical knowledge: systemic, analysis and synthesis, abstraction, and formal-logical approaches. Formal legal and comparative legal methods facilitated in covering the topic.

\section{Discussion and Result}

According to the estimates of international experts (that coincides with the estimate of the Minister of Finance of the Russian Federation A. Siluanov given during the International (ninth) Gaidar Forum "Russia and the World: Goals and Values", held on the basis of the Russian Academy of National Economy and Public Service under the President of the Russian Federation in January 2018), the phenomenon of stagnation and partially the economic crisis that occurred after 2008 was overcome by 2018. This applies both to the countries of Europe, and to the Russian Federation, to the states that are part of the Eurasian Economic Area (EEA), Russia is moving along the path of increasing the gross domestic product, developing high-tech industries of its national economy, diversifying the economy, and increasing the volume of production of agro-industrial products. This is to a certain extent promoted by the policy (since there are both negative and positive aspects for real sector of the economy) of sanctions against our country and counter-sanctions. Current Russia has been implementing the import substitution program in various industries, increasing the volumes of highquality production, building and reconstruction of production and social and cultural spheres. The further development of these processes positive for economic development requires the provision of stable conditions in the society, social and economic security in the country. First of all, the protection of the population of large and small cities, vehicles and ways of communication from threats to the lives and health of our citizens.

Problems of public safety exist, as it is now classified, at various levels and in various formats: global, international-regional, national-state. If global 
security affects the interests of most countries of the world, mankind as a whole, then the internationalregional affects groups of states and population of these countries located in a large region of the earth (like Eurasia). As a rule, there are similar problems, which means that it is necessary to find ways to solve them. Thus, problems of security become integrative for a number of states in one region of the world. Historically, similar to the problems of ensuring regional security, the tasks of ensuring Russia's national security have features largely common for the entire Eurasian space. At the same time, the measures taken in one large state to ensure its social security are in mutual influence and affect the situation in a number of other countries, most often - neighboring ones. Therefore, this problem goes beyond the narrow national scope.

The program document on the prospects for security, namely the Decree of the President of the Russian Federation "On the Approval of the National Security Strategy of the Russian Federation" of December 31, 2015 [1], considers the tasks of ensuring the security of the country as pivotal in the Russian Federation, providing primarily for protection of vital interests of the individual, society and state from external and internal threats. The Strategy directly states that these goals must be realized in cooperation with the solution of similar tasks in the countries of the European Union, the CIS, and the EEA. The previously existing potential threats have been extended with new challenges over the past few years. These include the challenges that create new realities in the social life of the society, which are formed largely under the influence of migration processes. In recent years, it has become clear that they carry significant threats to sustainable development, the stability of society in the countries of Western and Eastern Europe, Central Asia, and our state. A huge number of refugees to Europe from a number of Asian and North African countries includes, among other things, a significant number of people prone to asocial actions, i.e. deviant, and sometimes even delinquent behavior. It must be borne in mind that there are many religious fanatics, sectarians of extremist orientation, carriers of ideology among them, capable of giving rise to inadequate social reactions. A group disobedience to the norms of morality and ethics established in society, entails very dangerous consequences for the entire socio-cultural environment that has developed in our countries throughout the centuries of its cultural and historical evolution. Asocial behavior, which sometimes becomes a feature of groups of migrants, is both spontaneous in nature, and, often, organized and planned. These plans are built by those criminal groups who aim at striking at the stability of society in our countries. Newcomers, being involved in the ideology and practice of religious extremism in terrorist activities, have recently been often recruited from among the migrants. Sometimes they are replenished in this way by the number of convinced lone terrorists, sometimes - terrorist groups that carry real threats to the population of our cities and to quiet peaceful life.

What should we do to counter these dangers?

As a response to emerging challenges, a barrier to the development of such threats can be put both by measures aimed at improvement of the legislation (international and national), and by law enforcement practice. This is a separate specific topic, which this paper does not consider in detail.

It is extremely important to take the necessary actions in the country, along with enforcement measures, to ensure economic security as a key element in ensuring national security. The measures of ensuring economic security make it possible to carry out all other activities in the framework of defense, technological, environmental security, etc. The implementation of the economic security policy is a precondition for establishing and strengthening the social safety system that prevents threats to the society and the citizens. The provisions of the Decree of the President of Russia "On the Strategy of Economic Security of the Russian Federation for the Period until 2030" of May 13, 2017 [2] are focused on the above goal. This document deals with "national interests" as objectively significant economic needs of the population of our country, which satisfaction ensures the stability of the development of the state in the interests of all the peoples inhabiting it. At the same time, the Strategy for Economic Security of the Russian Federation directly refers to the expansion of interaction and integration relation within the framework of the Commonwealth of Independent States, the Eurasian Economic Union, BRICS, and the Shanghai Cooperation Organization as one of the important activities. It is clear that this emphasizes at the highest state level the similarity of conditions in the teeth of common challenges, common tasks of ensuring security of development, which require mutual cooperation. The potential of such international cooperation, intended to achieve significant positive results, has not yet been disclosed.

Another aspect of the activities aimed at preventing threats and neutralizing the risks of social and economic security also matters. One should not overlook such an important part of the organization of activities to counter threats to the security of society, its material and social stability, as a purposeful, often individual work with people who constitute a "risk group". The objects of this work should be people, first of all from external, and, in part, internal migrants, especially refugees, who carry a danger of 
victimization. Such people usually suffer from a number of psychological complexes and accentuations, with marked anger at the surrounding society, or a part of it. They could and should be recognized in advance by typical behavior, which is the tasks of both the relevant special services and social workers, municipal government bodies, and public organizations. It is extremely necessary today not only to identify such people, but also skillfully organize communication with them, neutralize their negative influence, and conduct social and preventive activities. This is a very difficult task. Putting on a mask, they often knowingly commit insignificant crimes in order to receive punishment as a short term of imprisonment and to get to detention facilities in this way. There, in "favorable" environment, they recruit new supporters of their extremist views, and potential terrorists. In 2017, the Research Institute of the Federal Penitentiary Service of Russia organized a special "round table" with international participation on the issues of prevention and overcoming of the involvement of citizens and stateless persons in extremist activity within the framework of the Penitentiary System. The materials of the "round table" clearly show about 2 thousand convicts involved in terrorism staying in its facilities around the country. Special work must be carried out with such a contingent, which requires specially trained personnel experienced in the field of migration and penal enforcement, law enforcement, social work [3]. It is necessary to organize such training of employees, most likely, on the basis of institutes of further education, departmental institutes for staff development. Positive examples of this kind are already available now - St. Petersburg and Novosibirsk institutes of professional development of the Federal Penitentiary Service of the Russian Federation, where similar curricula have been developed. This work attracted and engaged scientists of the research institute of the Federal Penitentiary Service of Russia, employees of the central office of the Service. Relevant classes with students of these schools have been conducted. However, this is not enough in already existing situation, reproduction of risks and counteraction from radical extremists.

\section{Summary}

Today, there is a pending need to develop more extensive relevant training courses and programs that include a significant amount of sociocultural knowledge, allows its students to master the techniques of socio-psychological diagnosis and correction, and acquire fundamentally new competencies enabling them holding discussions on the essence of pressing problems of society, overcoming negative trends in consciousness and behavior by persuasion. This will minimize the number of persons potentially able to replenish the number of members of extremist-oriented communities. It is crucial that the target audience for the work carried out by specially trained government officials (possibly in conjunction with representatives of traditional religions) would be young people who are in difficult life situation, including in penitentiary facilities, penal settlements, densely populated refugee camps, etc. It is expedient to organize a constant exchange of experience, educational and training materials between specialists of various government departments on this issue. Considering that many states are now facing similar problems in Eurasia, the solution of social security issues in this way become the problems of international regional security. It would be extremely useful to establish an international cooperation in the field of training personnel addressing social security problems. International cooperation in this area may become true in a short time. This will contribute to the staffing of regional antiterrorist cooperation, as a necessary precondition for addressing the issues of countering terrorist challenges. Threats of extremism and terrorism are one of the most dangerous our civilization has faced with at the present stage of its development. To overcome them is a common goal that should be reached jointly by methods and means that give attention to the sociocultural features and conditions in society [4].

\section{References}

[1] Ukaz Prezidenta Rossijskoj Federacii ot 12.05.2009 № 537 «O Strategii nacional'noj bezopasnosti Rossijskoj Federacii do 2020 goda». (In Russian)

[2] Ukaz Prezidenta Rossijskoj Federacii ot 13.05.2017 \# $208 \quad$ «O strategii ehkonomicheskoj bezopasnosti Rossijskoj Federacii na period do 2030 goda». (In Russian)

[3] Sbornik materialov kruglogo stola (30 noyabrya 2017 g., g. Moskva) / pod obshch. S.V. Garnika. M.: FKU NII FSIN Rossii, 2018. (In Russian)

[4] http://gaidarforum.ru/program/16-yanvarya/ (accessed 27 March 2018). 